\title{
Current Trends in Cuba on the Environmental Impact and Sustainable Development
}

\author{
Yanán Camaraza-Medina \\ Technical Sciences Faculty, Universidad de Matanzas, 44440, Cuba
}

Corresponding Author Email: ycamaraza1980@yahoo.com

https://doi.org/10.18280/ti-ijes.640116

Received: 13 November 2019

Accepted: 30 December 2019

\section{Keywords:}

environmental impact, current trends in

Cuba, gas emissions

\begin{abstract}
This technical note shows a summary of the current trends in Cuba on the environmental impact and sustainable development in the last five years. In this study, the country is sectioned in four regions, taking into account socioeconomic characteristics and similitude in conditions of development. In this paper, several elements are analyzed that have influence directly to the environmental impact, as, emissions of gases greenhouse effect, generation of electric power, water consumption, analysis of the air quality, implementation of renewable sources of energy, investments to mitigate the environmental impact, among others. The data set used in this material, was obtained from the report provided by the National Office of Statistic of the Cuba (ONEI). In this study is omitted the special municipality Isla de la Juventud.
\end{abstract}

\section{INTRODUCTION}

Cuba is a developing country, than even as the rest of the world receives the effects of the globalization and climatic change. At the present time, in Cuba it is worked up for the benefit of the sustainable development, guided to the reduction of gases of greenhouse effect, to the protection of waters and natural resources and to the proliferation of the use of the renewable sources of energy. For the purpose, the Cuban government has authorized the investment of over 2310 million of Cuban's pesos (MCP) in the last five years for works of environmental protection and mitigation [1].

Although previously studies were conducted on the use of electricity in $\mathrm{Cuba}$, in none of these was considered the local effect of production, consumption and $\mathrm{CO}_{2}$ emissions associated with it, (not including the adjacent keys). The production of electricity on the island of Cuba is highly dependent on fossil fuels. The fall of the socialistic block produced a severe crisis in the energy carriers in the country, since the main source of import of energy carriers was the Soviet Union [2].

In 2006, Cuba began a management of energy resuscitation, known as the "energy revolution". One of the elements associated with it is the entry into operation of power generation plants based on several units of low power generators, known in the country as an emerging generation.

In the last five years, the reanimation of the national economy has generated a sharp increase in electricity consumption; however, the national energy infrastructure has not been perfected. The degree of recapitalizations of the existing power plants has required that the emerging generation has been in charge of covering the new electricity requirements.

The Cuban state has undertaken the task of encouraging the use of renewable energy sources; however, the increase in generation with these sources does not compete with the rise in energy carrier needs [3].

The Cuban state has planned an investment that will allow the installation of $1650 \mathrm{MW}$ of power based in renewable energy, (solar, wind and biomass), which represents 24 percent of the national energy matrix. of these, $875 \mathrm{MW}$ correspond to 25 Biomass Power Plant (CEB) projects.

Recently, it was established law 124/2017, for the sake of protecting the subterranean and superficial waters; besides, there are several research projects and sustainable development, as they are, life, live coasts and energy efficiency.

In this technical note, is provided a brief overview of the state of generation and consumption of electricity in Cuba in the last five years. The study provides a focalization of each of the carriers for each of the country's fundamental regions. A relevant element to date does not have a similar material on the energy situation, the environmental impact and sustainable development in the country and the future prospects of this issue.

Additionally, several elements are analyzed that have influence directly to the environmental impact, as, emissions of gases greenhouse effect, generation of electric power, water consumption, analysis of the air quality, implementation of renewable sources of energy, investments to mitigate the environmental impact, among others.

\section{METHODS AND VALIDATION}

\subsection{Brief description of the object of study}

(1) The island of Cuba is made up of three fundamental regions, the occident, centre and orient. The Cuban capital (Havana) is considered in the present study as a fourth region, taking into account the conditions of very high population density that it presents. Figure 1 provides in detail the location of each of the provinces that make up the island of Cuba, in Table 1 the provinces that make up each region are detailed, while, in the Table 2 is given a summary of the demographics' distribution in Cuba for each region of study [4]. 


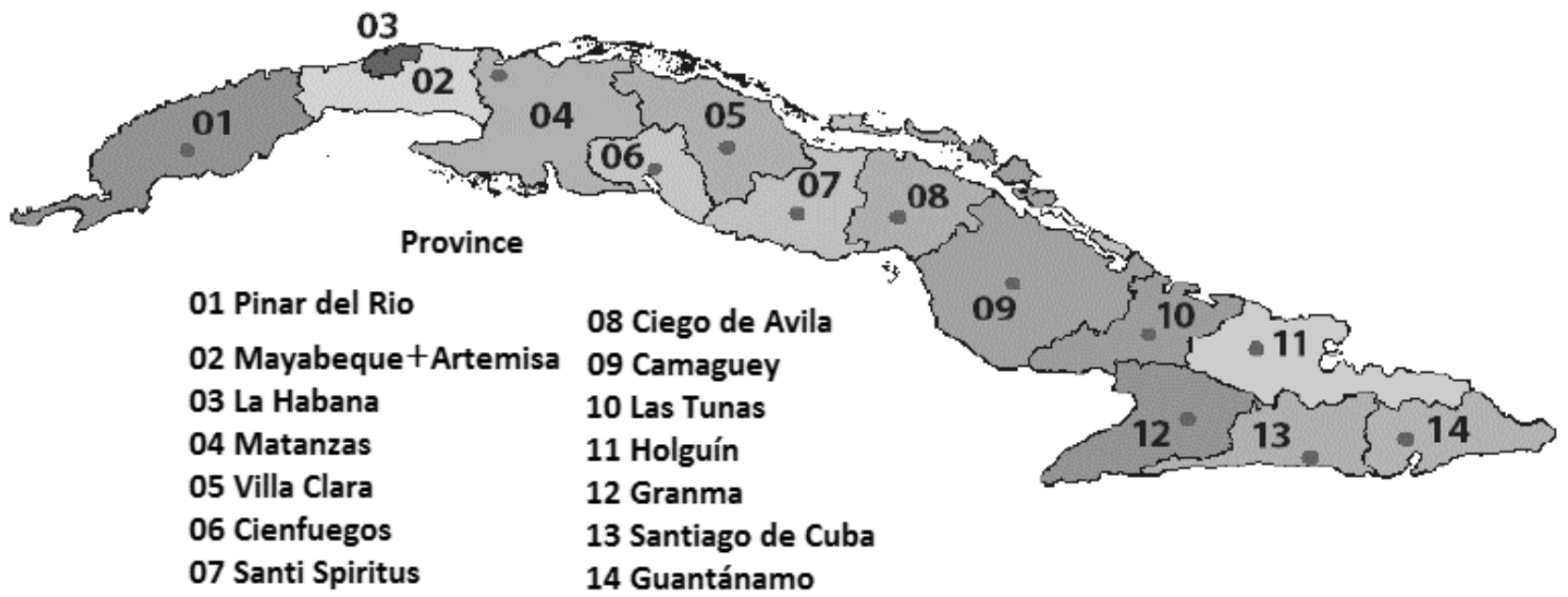

Figure 1. Location of the regional divisions of Cuba

Table 1. Location of the regional divisions of Cuba

\begin{tabular}{|c|c|}
\hline Region & Province members \\
\hline Occident & Pinar del Rio, Mayabeque+Artemisa and Matanzas \\
\hline Centre & $\begin{array}{c}\text { Villa Clara, Cienfuegos, Santi Spiritus, Ciego de Avila } \\
\text { and Camaguey }\end{array}$ \\
\hline Orient & $\begin{array}{c}\text { Las Tunas, Santiago de Cuba, Granma, Holguín and } \\
\text { Guantánamo }\end{array}$ \\
\hline Habana & La Habana \\
\hline
\end{tabular}

Table 2. Demographics distribution in Cuba for region

\begin{tabular}{|c|c|c|c|}
\hline Region & Inhabitants & Surface $\left(\mathrm{km}^{2}\right)$ & $\begin{array}{c}\text { Populousness } \\
\left(\mathrm{inh} / \mathrm{km}^{2}\right)\end{array}$ \\
\hline Occident & 2270520 & 28747 & 79 \\
\hline Centre & 2870880 & 38739 & 74.1 \\
\hline Orient & 3950830 & 36245 & 109 \\
\hline Habana & 2256650 & 751 & 3004.9 \\
\hline Cuba & 11348880 & 104482 & 108.6 \\
\hline
\end{tabular}

\subsection{Analysis of the consumption of electricity and water in Cuba}

In the last five years, the consumption of electricity has experienced an increasing tendency in Cuba, this is fundamentally, for the incorporation thousands of new clients to the National Electro Energetic Systems (SEN) that recently have been benefited with the national programs of electrification, and the majority is located in orient zone. In the Table 3 show a summary of the electricity consumption in the analyzed period (in GWh/year) for each region of study, while in the Table 4 is given the average consumption by inhabitants (in $\mathrm{kWh} /$ year).

The water consumption in Cuba is regulated according to the standard NC-973-2013. The global crisis of water has exerted its impact on Cuba, for this reason, at this moment exist a total of 24 plants in operation to make sea water drinkable, (fundamentally in the orient zone), with a processing capability of $0.05 \mathrm{~m}^{3} / \mathrm{s}$ each. The application of the law 124/2017 has established a control mechanism on the water use, for such motive the water consumption in the year 2018 is reduced with respect to the tendency to the consumption shown in prior years. In the Table 5 is given the global consumption of water in Cuba (in millions of $\mathrm{m}^{3}$ ) for each region in the studied period, while, in the Table 6 is given the average consumption (in $\mathrm{m}^{3}$ per inhabitants) in each region.
The data given in the tables 5 and 6 , correspond to the global consumption of water, that is than include activities on industrial purpose, agriculture and human consumption. In the Table 7 is proportionate a global summary of the water consumption in Cuba by each activity in the studied period

Table 3. Summary of the electricity consumption in the analyzed period, (in GWh/year)

\begin{tabular}{|c|c|c|c|c|c|}
\hline Region & 2014 & 2015 & 2016 & 2017 & 2018 \\
\hline Occident & 4043 & 4095 & 4148 & 4212 & 4284 \\
\hline Centre & 4405 & 4447 & 4489 & 4532 & 4542 \\
\hline Orient & 4250 & 4349 & 4450 & 4482 & 4511 \\
\hline Habana & 4117 & 4185 & 4254 & 4440 & 4490 \\
\hline Cuba & 16815 & 17076 & 17341 & 17666 & 17827 \\
\hline
\end{tabular}

Table 4. Summary of the electricity average consumption by inhabitants in the analyzed period (in $\mathrm{kWh} /$ year)

\begin{tabular}{|c|c|c|c|c|c|}
\hline Region & 2014 & 2015 & 2016 & 2017 & 2018 \\
\hline Occident & 1780.6 & 1803.6 & 1826.9 & 1855.1 & 1886.8 \\
\hline Centre & 1534.4 & 1549 & 1563.6 & 1578.6 & 1582.1 \\
\hline Orient & 1075.7 & 1100.8 & 1126.3 & 1134.4 & 1141.8 \\
\hline Habana & 1824.4 & 1854.5 & 1885.1 & 1967.5 & 1989.7 \\
\hline Cuba & 1481.6 & 1504.6 & 1528 & 1556.6 & 1570.8 \\
\hline
\end{tabular}

Table 5. Summary of the global consumption of water in the analyzed period (in millions of $\mathrm{m}^{3} /$ year)

\begin{tabular}{|c|c|c|c|c|c|}
\hline Region & 2014 & 2015 & 2016 & 2017 & 2018 \\
\hline Occident & 1430 & 1441 & 1468 & 1494 & 1407 \\
\hline Centre & 1768 & 1781 & 1792 & 1808 & 1741 \\
\hline Orient & 2538 & 2575 & 2598 & 2618 & 2458 \\
\hline Habana & 1444 & 1489 & 1552 & 1555 & 1412 \\
\hline Cuba & 7180 & 7286 & 7410 & 7475 & 7018 \\
\hline
\end{tabular}

Table 6. Summary of the water average consumption by inhabitants in the analyzed period (in $\mathrm{m}^{3} /$ year)

\begin{tabular}{|c|c|c|c|c|c|}
\hline Region & 2014 & 2015 & 2016 & 2017 & 2018 \\
\hline Occident & 629.9 & 634.6 & 646.7 & 658.2 & 619.9 \\
\hline Centre & 615.7 & 620.3 & 624.3 & 629.9 & 606.5 \\
\hline Orient & 642.3 & 651.8 & 657.5 & 662.6 & 622.2 \\
\hline Habana & 639.8 & 660 & 687.7 & 689.1 & 625.8 \\
\hline Cuba & 631.9 & 641.7 & 654.1 & 660 & 618.6 \\
\hline
\end{tabular}


Table 7. Summary of water removal by destinations

\begin{tabular}{|c|c|c|c|c|c|}
\hline \multirow{2}{*}{ Destiny } & \multicolumn{5}{|c|}{$\begin{array}{c}\text { Water consumption } \\
\text { (in millions of }{ }^{3} / \text { year) }\end{array}$} \\
\cline { 2 - 6 } & 2014 & 2015 & 2016 & 2017 & 2018 \\
\hline Gross freshwater extraction & 7567 & 7919 & 7805 & 8024 & 7348 \\
\hline Water returned without using & 387 & 633 & 395 & 549 & 348 \\
\hline Net freshwater withdrawal & 7180 & 7286 & 7410 & 7475 & 7000 \\
\hline By industry water supply & 1956 & 2627 & 2151 & 1773 & 1915 \\
\hline By other users & 5224 & 4659 & 5259 & 5702 & 5085 \\
\hline Superficial freshwater extraction & 4606 & 4573 & 4665 & 4558 & 4271 \\
\hline By industry water supply & 793 & 1461 & 1006 & 567 & 830 \\
\hline By other users & 3813 & 3112 & 3609 & 3991 & 3441 \\
\hline Groundwater extraction & 2574 & 2713 & 2795 & 2917 & 2729 \\
\hline By industry water supply & 1163 & 1166 & 1145 & 1206 & 1085 \\
\hline By other users & 1411 & 1547 & 1650 & 1711 & 1644 \\
\hline
\end{tabular}

\subsection{Analysis of the generation of electricity in Cuba}

In Cuba, the electricity generation is distributed throughout the country, although, the occident zone is the biggest producer of generation volume (approximately $40 \%$ of the total), however, it turns out to be the one with the lowest energy consumption.

The main sources of electricity generation in Cuba are:

1- Fuel Power Plants (FPP)

2- Energas Power Plant (GPP)

3- Fuel emerging generation (FEG)

4- Diesel emerging generation (DEG)

5- Biomass (B)

6- Renewable energy (RE)

Power plants are of two types, the first use liquid fuel and are based on the Rankine cycle, currently in the country there are 10 units, while the second type using gas turbines for the generation of electric power, currently have two units, one in Mayabeque and one in Matanzas.

The distributed generation considers the sites in which one or more generators with individual powers up to $1.5 \mathrm{MW}$ are located, which consume fuel oil or diesel.

The main source of electricity generation in Cuba with biomass is the sugar industry, while the renewable sources used are three fundamental types, solar photovoltaic, wind and hydraulic $[5,6]$.

The consumption of electric energy in Cuba has shown a clear rise in recent years, a graphic representation of the consumption of the last four years is provided in Figure 2, and it can be found that it follows a linear growing trend $[7,8]$.

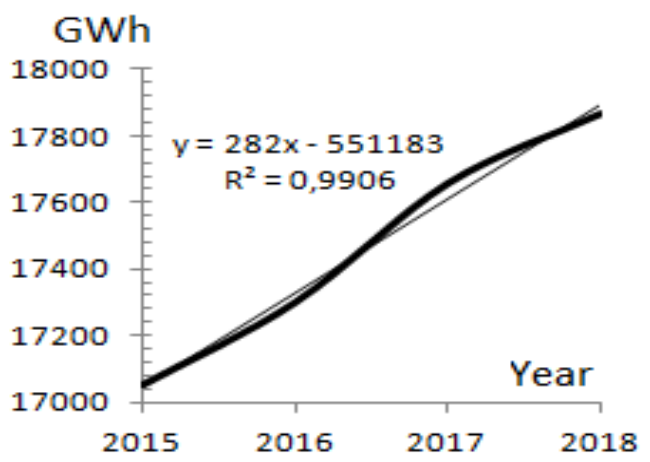

Figure 2. Growth of annual energy consumption in Cuba
This increase in electricity generation produces a clear increase in $\mathrm{CO}_{2}$ emissions. Figure 3 shows the growth of emissions associated with the generation of electricity in Cuba $[9,10]$.

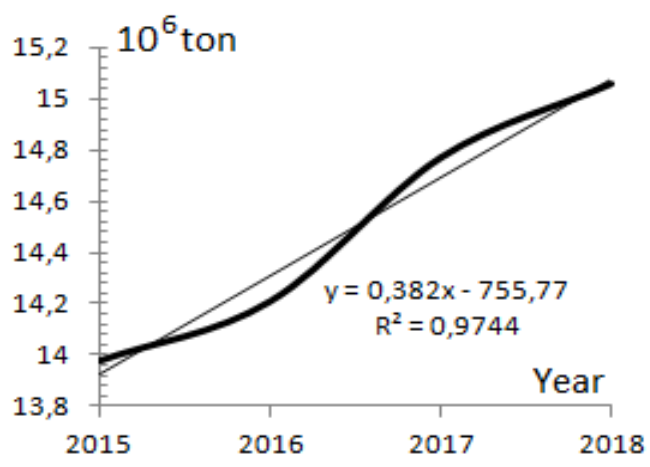

Figure 3. Growth of $\mathrm{CO}_{2}$ emissions due to the generation of electricity in Cuba

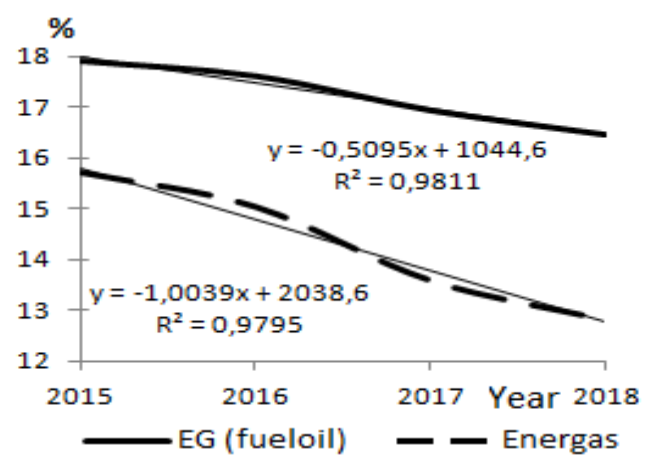

Figure 4. Percentage of participation in the electricity matrix in Cuba

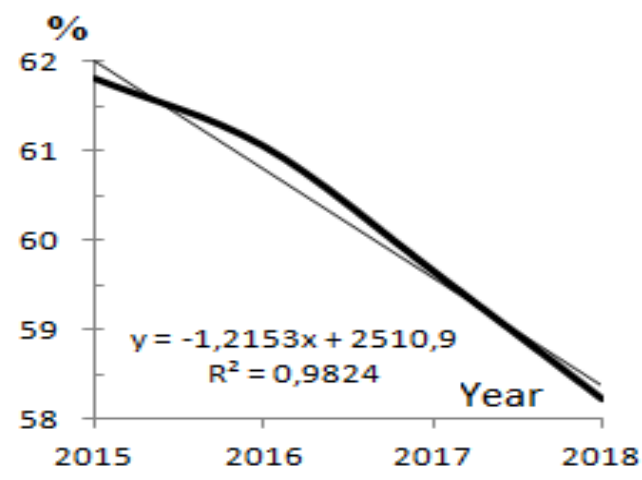

Figure 5. Percentage of participation of power plants in the electric matrix in Cuba

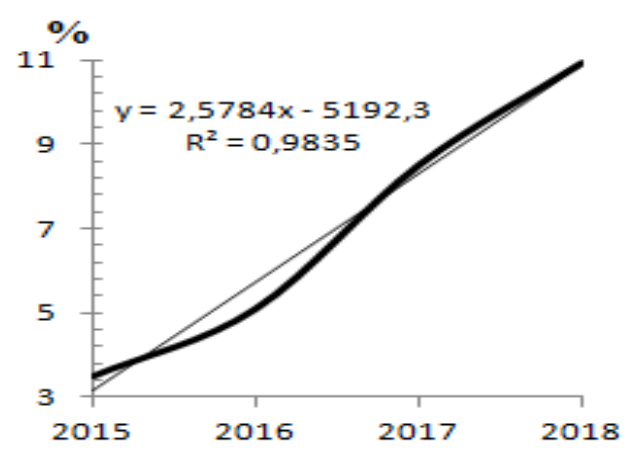

Figure 6. Percentage of participation of the emerging generation in the electricity matrix in Cuba 


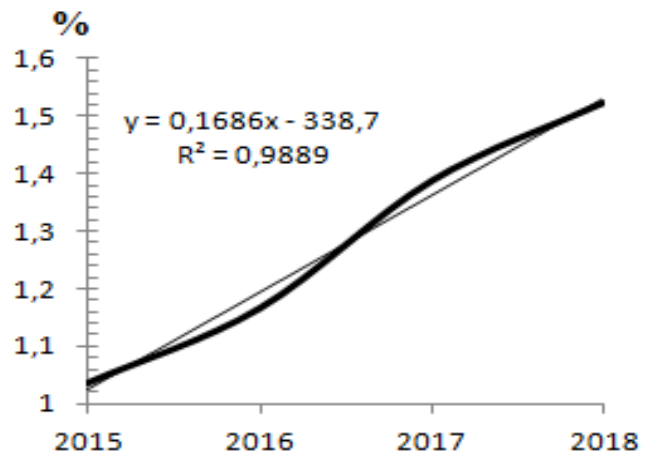

Figure 7. Percentage of participation of the renewable energy $\mathrm{n}$ the electricity matrix in Cuba

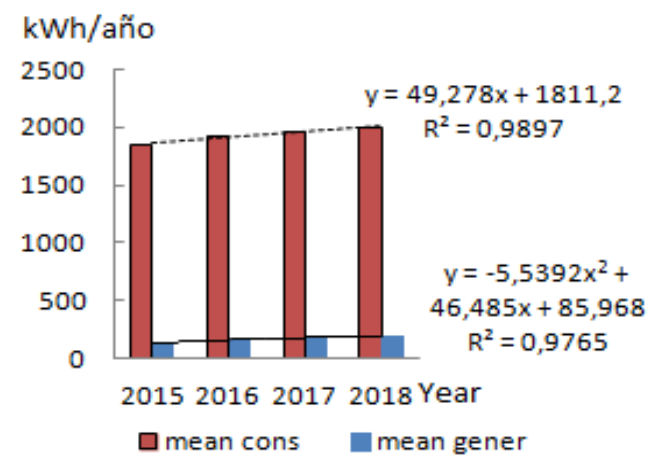

Figure 8. Consumption and the average generation per inhabitant in Habana

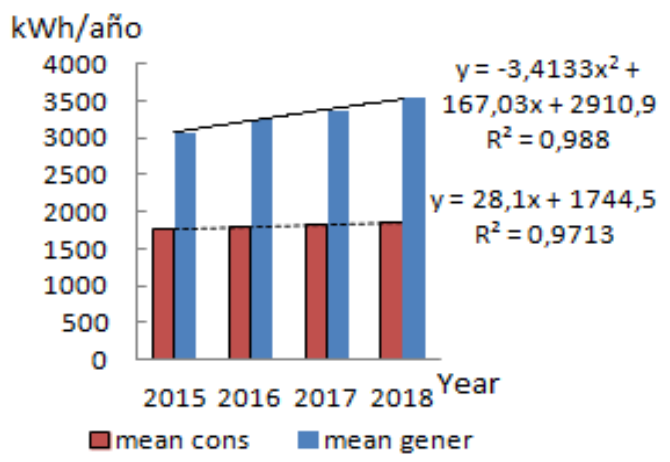

Figure 9. Consumption and the average generation per inhabitant in Occident

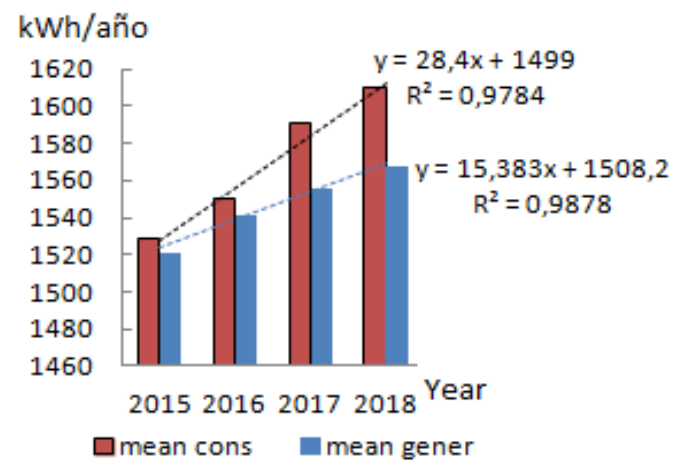

Figure 10. Consumption and the average generation per inhabitant in Centre

The individual participation of each generation source in the production of electricity in Cuba is given in Figures 4 to 9. In each of them, the percentage value represented by each individual source of the total generation delivered in the last 4 years is detailed. The accelerated growth of the presence in the energy matrix of the emerging generation can be verified.

In Cuba, consumption and electricity generation are not distributed equally in each of the regions. When establishing the average energy demand per inhabitant, it is found that in Havana, it turns out to be almost twice as high as in the Orient. In the case of generation, the Occident zone is the one that provides the highest average per customer; however, it turns out to be the second lowest consumption. In Figures 8 to 11 consumption and the average generation per inhabitant are plotted for each of the regions of Cuba.

In order to apply the given correlations in the Figures 10 to 11 , the variable $\mathrm{x}$ refers to the year to analyze, taking the year 2015 as year 1 .

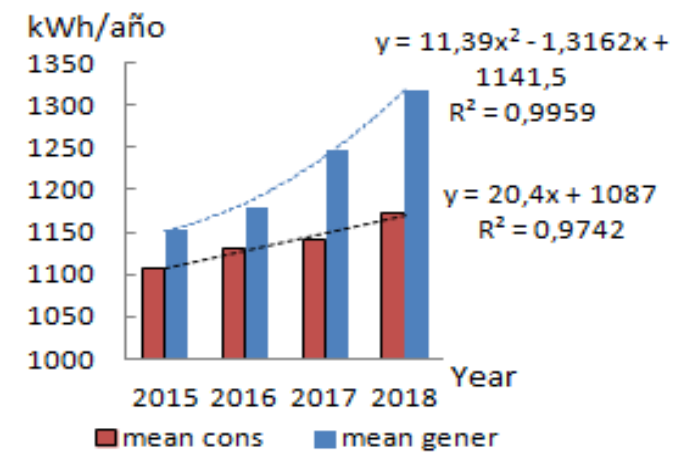

Figure 11. Consumption and the average generation per inhabitant in Orient

\section{BRIEF ANALYSIS OF THE ENVIRONMENTAL CURRENT STATE OF CUBA}

\subsection{Summary of the main actions of mitigation executed in Cuba}

At the present time, in Cuba it is worked up for the benefit of the sustainable development, guided to the reduction of gases of greenhouse effect, to the protection of waters and natural resources and to the proliferation of the use of the renewable sources of energy. For the purpose, the Cuban government has authorized the investment of over 2310 million of Cuban's pesos (110 million USD) in the last five years for works of environmental protection and mitigation. In the Table 8 is given in more details of this investment for environmental protection in Cuba [11].

Table 8. Expenses for environmental protection in Cuba, (in MCP)

\begin{tabular}{|c|c|c|c|c|c|}
\hline Environmental sector & 2014 & 2015 & 2016 & 2017 & 2018 \\
\hline Waters & 226.4 & 239.4 & 243.9 & 245.7 & 258.4 \\
\hline Soils & 17.5 & 18.1 & 18.5 & 23.6 & 32.2 \\
\hline Atmosphere & 49.9 & 56.6 & 61.1 & 64.7 & 67.6 \\
\hline Forest resources & 65.5 & 74.7 & 77.4 & 122.1 & 126.6 \\
\hline Solid resources & 20.8 & 13.8 & 12.4 & 10.4 & 24.7 \\
\hline Others & 24.7 & 26 & 22 & 3.5 & 64.6 \\
\hline Total & 404.8 & 428.6 & 435.3 & 470 & 574.1 \\
\hline
\end{tabular}

In the Table 9 are given the expenses for water protection by provinces, in MCP. 
Correlating the average cost of water protection and its average consumption, it is obtained that the best fit is given by an exponential function, with an approximation coefficient $\left(\mathrm{R}^{2}=0,953\right)$, being described by $[12,13]$ :

$$
G_{\text {Usoagua }}=0,145 \cdot e^{0,0596\left(W_{R}\right)}
$$

In the Eq. (1), $G_{U \text { Usoagua }}$ is the financial expense associated to the mitigation of the environmental impact, in $\$ / \mathrm{m}^{3}$ and $W_{R}$ is the yearly consumption of water, in $\mathrm{m}^{3}$.

Table 9. Expenses for water protection by province

\begin{tabular}{|c|c|c|c|c|c|}
\hline Province & 2014 & 2015 & 2016 & 2017 & 2018 \\
\hline Pinar del Río & 9.3 & 9.4 & 8.7 & 10.3 & 15.8 \\
\hline Artemisa & 1.1 & 0.8 & 3.4 & 2.1 & 16.6 \\
\hline La Habana & 49.2 & 49.4 & 47.2 & 53.3 & 66.5 \\
\hline Mayabeque & 1.2 & 0.2 & 0.6 & 0.8 & 5.7 \\
\hline Matanzas & 15.5 & 14.7 & 65.6 & 47.5 & 15.6 \\
\hline Villa Clara & 15.1 & 16.2 & 8.2 & 13.4 & 29.3 \\
\hline Cienfuegos & 3.1 & 6.5 & 6.2 & 4.9 & 6.9 \\
\hline Santi Spíritus & 5 & 10.8 & 6.8 & 6.4 & 5.4 \\
\hline Ciego de Ávila & 4.2 & 6.1 & 7.6 & 9.2 & 9.5 \\
\hline Camagüey & 8.1 & 7.9 & 7.8 & 9.6 & 9.7 \\
\hline Las Tunas & 4 & 10.7 & 8.7 & 7.3 & 5 \\
\hline Holguín & 40.4 & 35.4 & 40.3 & 34.3 & 30.8 \\
\hline Granma & 11.3 & 13.6 & 15.5 & 17.5 & 10.6 \\
\hline Santiago de Cuba & 48.3 & 47.6 & 8.4 & 18.8 & 18.4 \\
\hline Guantánamo & 9.8 & 10 & 8.8 & 10.1 & 11.1 \\
\hline Total & 226.4 & 239.4 & 240.9 & 245.7 & 258.4 \\
\hline
\end{tabular}

The uses of Eq. (1) allows verifying that the average cost of mitigation required by each $\mathrm{m}^{3}$ of water round the intervals given in the bibliographic analysis [5], however, due to the critical state of some local basins. the values determined with Eq. (1) can provide to be a 60 percent smaller than the real value.

In the Table 8 can check that nearly to 13 percent of the investment expenses for protection to the environment in the five year period 2013-2018 were dedicated to the atmosphere. For this reason, in the Table 10 is offers a summary of the main emissions of contaminating gases in the country in said period. according to the reports of ONEI [3].

Table 10. Summary of the main emissions of contaminating gases in Cuba, (in $\mathrm{Gg}$ )

\begin{tabular}{|c|c|c|c|c|c|c|}
\hline Year & $\mathrm{CO}_{2}$ & $\mathrm{CH}_{4}$ & $\mathrm{~N}_{2} \mathrm{O}$ & $\mathrm{NO}_{X}$ & $\mathrm{CO}$ & $\mathrm{SO}_{2}$ \\
\hline 2013 & 27973.8 & 354.8 & 11.7 & 97.1 & 546.4 & 462.7 \\
\hline 2014 & 26586.1 & 365.8 & 11.1 & 96.8 & 602.8 & 513.6 \\
\hline 2015 & 24892.9 & 398.4 & 9.8 & 84.3 & 502.2 & 614.5 \\
\hline 2016 & 24233.8 & 400.4 & 7.3 & 82.9 & 494.7 & 665.8 \\
\hline 2017 & 26532.4 & 103.7 & 8.5 & 104.9 & 450.8 & 780.3 \\
\hline 2018 & 30060.9 & 372.9 & 8.2 & 97.7 & 370.5 & 835.6 \\
\hline
\end{tabular}

The correlation of the expenses for the concept of protection to the atmosphere with the estimated emissions in 2018 allows us to establish with an approximation coefficient $\left(R^{2}=0.987\right)$ an expression for the determination of expenses based on greenhouse gas emissions, this expression is given by [5]:

$$
G_{\text {Emis }}=3,911 \cdot A \cdot e^{0,226 \cdot B}
$$

where,

$$
\begin{gathered}
A=\operatorname{Ln}\left(\left(\mathrm{CO}_{2}\right)^{0,1} \cdot \mathrm{SO}_{2}\right)^{0,1}+0,252 \\
B=\log \left[\frac{\left(\mathrm{CH}_{4} \cdot \mathrm{NO}_{\mathrm{X}} \cdot(\mathrm{CO})^{0,04}-\left(\mathrm{SO}_{2}\right)^{2}\right)^{2}}{\mathrm{~N}_{2} \mathrm{O}}\right]
\end{gathered}
$$

In Eqns. (3) and (4), the volumes of polluting gases are given in $\mathrm{Gg}$.

\section{CONCLUSIONS}

In the last five years, in Cuba there is a clear tendency to increase the presence of the emerging generation within the national energy matrix. An unequal distribution of energy carriers between the different regions of the country was shown, being established that Habana consumes almost twice the average energy carriers per inhabitant than the rest of the country, and accompanied by a low rate of electricity generation.

In this paper, several elements are analyzed that have influence directly to the environmental impact, as, emissions of gases greenhouse effect, generation of electric power, water consumption, analysis of the air quality, implementation of renewable sources of energy, investments to mitigate the environmental impact

The application of the law 124/2017 has established a control mechanism on the water use, for such motive the water consumption in the year 2018 is reduced with respect to the tendency to the consumption shown in prior years.

Two expressions of calculation were developed for the analysis of the costs of mitigation by emissions of the greenhouse effect gases, as well as for the water uses.

\section{REFERENCES}

[1] Camaraza-Medina, Y., Hernández-Guerrero, A., Luviano-Ortiz, J.L, Cruz-Fonticiella, O.M., GarcíaMorales, O.F. (2019). Uses of air-cooled condenser in thermoelectric power plant of biomass: A study case. Centro Azúcar, 46(2): 21-34.

[2] Suárez, J.A. (2019). Energy, environment and development in Cuba (original text In Spanish), Editorial Oriente, Santiago de Cuba, Cuba, 124-177.

[3] ONEI, Estadísticas energéticas de la revolución, 2019. Oficina Nacional de Estadística, La Habana, Cuba, 2020 Available in: http://www.one.cu/aec2019.htm, accessed on Jan. 172020

[4] Sagastume-Gutiérrez, A., Cabello-Eras, J.J., Vandecasteele, C., Hens, L. (2018). Data supporting the assessment of biomass based electricity and reduced GHG emissions in Cuba. Data in Brief, 17: 716-723. https://doi.org/10.1016/j.dib.2018.01.071

[5] Camaraza-Medina, Y. (2019). Methods for the determination of the heat transfer coefficient in air cooled condenser used at biomass power plants. Ph.D Thesis, Universidad Central "Marta Abreu" de Las Villas, Cuba, 1-100.

[6] Camaraza, Y. (2017). Introducción a la termo transferencia. Editorial Universitaria, La Habana.

[7] MINEM, Boletín de energía, 2019. Ministerio de Energía 
y Minas, La Habana, Cuba, 2020 Available in: http://www.minem.gob.cu/energ2019.htm, accessed on Jan. 92020.

[8] DNC, Generación eléctrica en Cuba. (2019). Despacho Nacional de Carga, La Habana, Cuba, 2020 Available in: http://www.dnc.une.cu/generacion2019.htm, accessed on Jan. 122020.

[9] Camaraza-Medina, Y., Cruz-Fonticiella, O.M., GarcíaMorales, O.F. (2018). Predicción de la presión de salida de una turbina acoplada a un condensador de vapor refrigerado por aire. Centro Azúcar, 45(1): 50-61.

[10] Camaraza-Medina, Y., Hernández-Guerrero, A., Luviano-Ortiz, J.L., Cruz-Fonticiella, O.M., GarcíaMorales, O.F. (2018). Metodología para la evaluación de plantas de potencia que operan con sistemas de condensación secos. Centro Azúcar, 45(4): 150-162.

[11] Camaraza-Medina, Y., Hernández-Guerrero, A., Luviano-Ortiz, J.L., Cruz-Fonticiella, O.M., García-
Morales, O.F. (2019). Empleo de condensadores secos en centrales termoeléctricas de biomasa: un caso de estudio. Centro Azúcar, 46(2): 21-34.

[12] Camaraza-Medina, Y., Hernández-Guerrero, A., Luviano-Ortiz, J.L., Mortensen-Carlson, K., CruzFonticiela, O.M., García-Morales, O.F. (2019). New model for heat transfer calculation during film condensation inside pipes. International Journal of Heat and Mass Transfer, 128: 344-353. https://doi.org/10.1016/j.ijheatmasstransfer.2018.09.012

[13] Camaraza-Medina, Y., Hernandez-Guerrero, A., Luviano-Ortiz, J.L., Cruz-Fonticiella, O.M., GarcíaMorales, O.F. (2019). Mathematical deduction of a new model for calculation of heat transfer by condensation inside pipes. International Journal of Heat and Mass Transfer, 141:

$180-190$. https://doi.org/10.1016/j.ijheatmasstransfer.2019.06.076 